\title{
Modern Mobile App for Assessing the SWOT Report for Buisness Professionals
}

\author{
G. Anandhi, K. Thiyagarajan, N. Mathan Kumar
}

\begin{abstract}
Womens builds up the family, which prompts Society and Nation. Female business visionaries make basic responsibilities to money related improvement and to desperation decline. This hypothetical are shows the activity and underscores the women specialists as the possibly rising human resource in the 21st century to beat the financial challenges in worldwide particular. This are conducts an investigation that is classes into three areas: First segment dependent on execution and job of ladies business visionaries answer Analysis. Second area dependent on the guide and short gave by government broadly and universally $u$ degree to ladies as Entrepreneurs. Third area centers around the most powerful and optimistic effective Women Entrepreneurs in India. These ladies chiefs are decisive, convincing and ready to go for broke. They figured out how to endure and prevail in this focused world and willing to capably their center competency with their diligent work, steadiness and obseverance. The are discussions about the status of ladies business people and the issues looked by them; at the same time they are gives an understanding into the difficulties looked by ladies business people. In any case, business enterprise improvement and aptitude preparing isn't the main duty of Government. And furthermore much credit can be given to business for the and development of blended economy culture in creating nation like India. The detest are attempts to ponder the idea of ladies business visionary and talk about the patterns and issues in the advancement of different fields. It will likewise recommend the method for eradicate and diminishing obstacles of the ladies enterprise advancement through investigation of SWOT study in Indian Context and to make due in the Globalized world
\end{abstract}

Keywords: Financial challenges, Entrepreneurs, Diminishing obstacles, SWOT Analysis

\section{INTRODUCTION}

Ladies business visionaries have been selected to carry flourishing and security to the new development motors and the rising stars of the creating nations ' economies. Ladies Entrepreneurs can be portrayed as ladies or a gathering of ladies setting up, arranging and maintaining a business[1]-[6]. The Government of India has portrayed ladies business visionaries as a business possessed and constrained by ladies with a base monetary enthusiasm of 51 blunder penny of the capital and giving ladies in any event $51 \%$ of the employments delivered in the organization.

Revised Manuscript Received on December 11, 2019

G. Anandhi, Department of Science and Humanities, Bharath Institute of Higher Education and Research, Chennai , India Email: anandhi5679@gmail.com

K. Thiyagarajan, Department of Science and Humanities, Bharath Institute of Higher Education and Research, Chennai, India Email: thiyagu768@gmail.com

N. Mathan Kumar, Department of Science and Humanities, Bharath Institute of Higher Education and Research, Chennai, India Email: ma.aswinkumar18@gmail.com
The development of the segment of ladies business visionaries in creating nations has drawn the consideration of both the scholastic and the improvement part. Ladies business visionaries occupied with business because of us and all components which urge ladies to have a free occupation and stands without anyone else legs[2]-[7]. Affected by these elements the ladies business person picks a calling as a test and as a desire to experiment.

\section{OBJECTIVES}

1. To analyse the Government participation against the ladies business people advancement program in India.

2. To examine the SWOT study of Women Entrepreneurs in India

3. To assess the elements liable for urging ladies to become business visionaries

4. To distinguish the variables answerable for deterrent for ladies business

5. To make an assessment of job's idea and sentiment about ladies business in India

\section{REVIEW OF LITERATURE}

The development of the segment of ladies business people in creating nations has drawn the consideration of both the scholastic and the advancement part. Ladies Entrepreneur in India The business person sorts out and works an undertaking for individual increase[8]-[11]. He contributes his own drive, expertise, and resourcefulness in arranging, sorting out, and overseeing the venture. He likewise accept the opportunity of misfortune and addition resulting to unanticipated and wild conditions. The net buildup of the yearly receipts of the enter the sum total of what expenses have been help, he holds for himself. In the late nineteenth and mid twentieth hundreds of years, business visionaries were as often as possible not recognized from chiefs and were seen for the most part from a monetary erective.

\section{RESULTS AND DISCUSSIONS}

\section{A. SWOT Analysis:}

A parameter to look at the development and execution of ladies business people's improvement in India.

\section{B. Quality}

Ladies business visionary can be characterized as a sure, inventive and innovative ladies link of complete self financial autonomy exclusively or in joint effort, produce work fortuities for others through starting, building family and public activity. 
Ladies allude to work from their very own home, trouble in landing reasonable positions and want for social acknowledgment persuades them independent work

\section{Shortcomings}

Non-appearance of short thunder, engagement and back-u for women by their own relatives and the work of the outside world constrain them to fall exceeding standards in the field of endeavor. However, family commitments for women prohibit them from becoming effective business visionaries in both established and developing nations. Achievement inspiration of the ladies people discovered less contrasted with male members. ${ }^{\bullet}$ The best impediment to ladies business people is that they are ladies.

\section{Opportunity}

Ladies teach innovative qualities and include significantly in business dealings. Business fortuities that are suggesting for ladies business visionaries are eco-accommodating innovation, Bio-innovation, IT empowered endeavors, occasion the board, traveler industry, foods processing. Women business people profit new fortuities in the rustic territories, for example, Ice-cream, station items, helps and pickles and Readymade articles of clothing[12]-[15].

\section{E. Threats}

Credit racism and officials who are not cooperative.

Insecure and our networks as well as working with male workers.

Indian women focus on family ties and friendships.

\section{F. Sets Taken by the Indian Government First sets taken in Seventh Five-Year land}

Explicit target gathering: It was recommended to regard ladies as a particular target bunches in all significant advancement projects of the nation

Masterminding preparing offices: It is likewise proposed in the part to devise and enhance professional preparing offices for ladies.

Growing new types of gear: Efforts ought to be made to expand their proficiency and efficiency through arrogate advancements, types of gear anorectics

Promoting help: It was recommended to give the necessary help to showcasing the items created by ladies entrepreneurs. Decision-production break: It was likewise proposed to include the ladies uncertainty making break.

\section{G. Second steps taken by Government during Eight Five-Year handles:}

The Indian government concocted social projects to builds work and salary producing exercises for ladies in provincial zones. The accompanying grounds are dined during the Eight-Five Year land head administrator Rojgar Yojana and EDs were acquainted with create enterprising characteristics among rustic ladies.

" Women in agribusiness" plot was acquainted with train ladies farmer shaving little and minor property in horticulture and partnered exercises

2. To create greater business fortuities for ladies KVIC took social measures in remote zones.
3.Women co-oeratives plans were framed to help ladies in agro-based businesses like dairy cultivating, oultry, creature farming, agriculture and so forth with full budgetary short from the Government

\section{H. Third Sets taken by Government during Ninth Five-Year land:}

Economic improvement and development isn't accomplished completely without the advancement of ladies business people. The Government of India has presented the accompanying plans for advancing ladies business enterprise in light of the fact that the eventual fate of little scale ventures relies on the ladies business visionaries:

1. TREAD scheme was propelled by Ministry of Small Industries to create ladies business visionaries in rustic, semi-urban and urban territories by developing entrereneurial characteristics[16]-[19].

2. Ladies Comk0onent lant, a social technique ado0ted by Government torovide help to ladies business visionaries.

3. Swaran Jayanti Sekhari RozgarYojana were acquainted by government with give reservations to ladies andencouraging them to begin their endeavors

4. New plans named Women Development Corporations were acquainted by government with assistance ladies business visionaries in masterminding credit and showcasing facilities. State Industrial and Development Bank of India (SIDBI) has acquainted after plans with help the ladies business people.

\section{Fourth Consortium of Women business visionaries of India}

Provides a latform toassist the ladies business visionaries to grow new, inventive and creative systems of generation, fund and advertising. There are various bodies, for example, NGOs, deliberate associations, Self-help gatherings, establishments and individual ventures from rustic and urban regions which by and large help the ladies business people in their exercises.

\section{J. Fifth Training developers:}

The accompanying preparing plans particularly for theself work of ladies are presented by government:(i)Support for Training and Employment modified of Women (STE).(ii)Development of Women and Children in Rural Areas (DWCRA)[20]-[22]

\section{K. 6th Mahila Vikas Nidhi:}

SIDBI has built up this reserve for the entrereneurialdeveloment of ladies particularly inrural territories.

\section{Seventh Rashtriya Mahila Kosh:}

In 1993, Rashtriya Mahila Kosh was set u togrant smaller scale credit to mineral ladies at sensible paces of enthusiasm with very lowtransaction costs and simle rocedures[23]-[25].

\section{CONCLUSION}

India is a developing country and is understood to be efficiently and socially reliant on male members with a mixed economy, male dominated society, and women. Women 
entrepreneurs have basic indigenous knowledge,

skills, potential and resources to set up and manage businesses, but at the same time many problems such as lack of education, social barriers, legal role of women entrepreneurs in India: Ladies have the potential and assurance to set up and oversee their very own business in an extremely orderly way, to help and support society, family, and government to make these ladies business people a craft of the national economy and to add to India's monetary advancement.

\section{REFERENCES}

1. Vasanthi, S. \& Rabiyathul Basariya, S. 2019, "Influence of value analysis and cross training in industry", International Journal of Engineering and Advanced Technology, vol. 8, no. 6, pp. 1810-1811.

2. Velvizhi, R., Sri Gowtham, S. \& Jeya Priya, D. 2019, "Examination of early feedbacks for effective product retailing on E-commerce websites", International Journal of Engineering and Advanced Technology, vol. 8, no. 6 Special Issue 2, pp. 703-706.

3. Anuradha, C., Pothumani, S. \& Kavitha, R. 2019, "A novel method towards E-commerce", International Journal of Engineering and Advanced Technology, vol. 8, no. 6 Special Issue 2, pp. 535-538.

4. Thomas, J. \& Rabiyathul Basariya, S. 2019, "A study on the issues of financial ratio analysis", Indian Journal of Public Health Research and Development, vol. 10, no. 3, pp. 1079-1081.

5. Ramachandran, S. \& Rabiyathul Basariya, S. 2019, "Online marketing study on customer satisfaction and relationship", Indian Journal of Public Health Research and Development, vol. 10, no. 3, pp. 1072-1078.

6. Priya, R., Vinothini, G. \& Cor Jesu, C.D. 2019, "The mentor-protégé relationship for professional growth", Journal of Advanced Research in Dynamical and Control Systems, vol. 11, no. 9 Special Issue, pp. 1110-1119.

7. Jannifer Rani, N., Bina Pani, S. \& Nimisha, N.S. 2019, "A study on money back polices available in LIC", Journal of Advanced Research in Dynamical and Control Systems, vol. 11, no. 9 Special Issue, pp. 833-839.

8. Saillaja, V., Jhansi Rani, K. \& Catherine, R. 2019, "Global marketing management planning and organization", Journal of Advanced Research in Dynamical and Control Systems, vol. 11, no. 9 Special Issue, pp. 489-493.

9. Saillaja, V., Jhansi Rani, K. \& Catherine, R. 2019, "The new phase of marketing information system", Journal of Advanced Research in Dynamical and Control Systems, vol. 11, no. 9 Special Issue, pp. 482-488.

10. Thoufiqulla \& Raju, D.V. 2019, "Perception of indian investor towards investment in mutual funds with special reference to mip funds", Journal of Advanced Research in Dynamical and Control Systems, vol. 11, no. 5, pp. 177-183.

11. Jasmine, K.R.M. \& Basariya, S.R. 2018, "A study on the customers benefits on mutual funds", International Journal of Civil Engineering and Technology, vol. 9, no. 4, pp. 45-48.

12. Vasanthi, S. \& Basariya, S.R. 2019, "Pros and cons of on the job training versus off the job training", International Journal of Scientific and Technology Research, vol. 8, no. 10, pp. 671-674.

13. Pavithra, J. \& Ganesan, M. 2016, "A study on awareness and impact of micro-financial schemes", International Journal of Applied Busines and Economic Research, vol. 14, no. 8, pp. 5449-5460.

14. Pavithra, J., Dilli Babu, P. \& Ambuli, T.V. 2014, "A study on budgetary control at Maruti Service Masters, Chennai", International Journal of Applied Business and Economic Research, vol. 12, no. 2, pp. 151-161.

15. Gunaraja, T.M. \& Venkatrama Raju, D. 2018, "Determining factors of organisational climate with reference to leadership styles", International Journal of Mechanical Engineering and Technology, vol. 9, no. 9, pp 1327-1332.

16. Gunaraja, T.M. \& Venkatrama Raju, D. 2018, "The role of job satisfaction and training of employees in determining organisational climate of a selected industry", International Journal of Civil Engineering and Technology, vol. 9, no. 8, pp. 1266-1269.

17. Aarathy, T.S. \& Raju, D.V. 2018, "Performance appraisal and its effects on employees with respect to it sector in Chennai city", International Journal of Civil Engineering and Technology, vol. 9, no. 6, pp 1535-1538.

18. Aarathy, T.S. \& Raju, D.V. 2018, "Employee perception towards performance appraisal system in IT sector", International Journal of Mechanical Engineering and Technology, vol. 9, no. 5, pp. 131-135.
19. Porselvi, W., Jublee, D. \& Sivanesan, G. 2018, "A study on factors influencing adoption of technology and innovation in banking industry, tamilnadu, India", International Journal of Mechanical Engineering and Technology, vol. 9, no. 5, pp. 789-800.

20. Akessa, G.M. and Dhufera, A.G., 2015. Factors That Influences Students Academic Performance: A Case of Rift Valley University, Jimma, Ethiopia. Journal of Education and Practice, 6(22), pp.55-63.

21. Miller, G. and Shih, C.C., 1999. A faculty assessment of the academic rigor of on-and off-campus courses in agriculture. Journal of Agricultural Education, 40, pp.57-65.

22. Tsinidou, M., Gerogiannis, V. and Fitsilis, P., 2010. Evaluation of the factors that determine quality in higher education: an empirical study. Quality Assurance in education, 18(3), pp.227-244.

23. Farooq, M.S., Chaudhry, A.H. Shafiq, M. and Berhanu, G., 2011. Factors affecting students' quality of academic performance: a case of secondary school level. Journal of quality and technology management, 7(2), pp.1-14

24. Fitsilis, P., Gerogiannis, V. and Anthopoulos, L., 2014. Ontologies for software project management: a review. Journal of Software Engineering and Applications, 7(13), p.1096.

25. Adams, J.D. and Jaffe, A.B., 1996. Bounding the effects of R\&D: an investigation using matched establishment-firm data(No. w5544). National bureau of economic research.

\section{AUTHORS PROFILE}

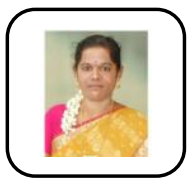

G. Anandhi Assistant Professor, Department of Science and Humanities, Bharath Institute of Higher Education and Research, Chennai, India.

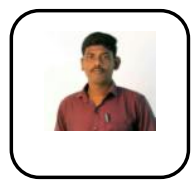

K. Thiyagarajan Assistant Professor, Department of Science and Humanities, Bharath Institute of Higher Education and Research, Chennai , India.

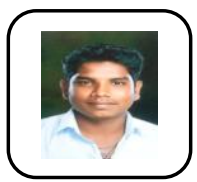

N. Mathan Kumar Assistant Professor, Department of Science and Humanities, Bharath Institute of Higher Education and Research, Chennai, India. 